COCOS (1998-99), 13, 30 - 39

Printed in Sri Lanka

\title{
GENETIC IMPROVEMENT OF THE COCONUT CULTIVAR SAN RAMON
}

\author{
W M U Fernando
}

\author{
Coconut Research Institute, Lunuwila, Sri Lanka
}

\begin{abstract}
The tall form of coconut, San Ramon was imported to Sri Lanka from the Philippines and was first established in the North Western Province. The open pollinated seed obtained from the first introduction and planted at the Coconut Research Institute (CRI), form the genetic base for San Ramon improvement at present. This cultivar inherits the potential of producing $51 \%$ more copra per nut than Sri Lanka Tall palms and 50\% more copra per nut than the improved tall, CRIC 60 . The mean copra yield per nut recorded for San Ramon (selfed), Sri Lanka Tall and CRIC 60 was $371 \mathrm{~g}, 240 \mathrm{~g}$ and $246 \mathrm{~g}$ respectively. Preliminary investigations have shown that the oil extraction efficiency of copra is $776 \mathrm{ml}$ per kg of copra for Tall $x$ San Ramon whilst for both Sri Lanka tall and CRIC 60 , it is $740 \mathrm{ml}$. The results of this study strongly justify the use of San Ramon and its crosses for copra and oil industry in Sri Lanka.
\end{abstract}

\section{INTRODUCTION}

It is believed that the first introduction of San Ramon was made by private growers and was planted at the Clovis Estate, Uhumiya, Kurunegala in the North Western Province of Sri Lanka (CRI 1987). A few seedlings arising from open pollinations of the Clovis introduction was planted at the Bandirippuwa Estate (BE), Lunuwila and these palms were used as parents to raise selfed and outcrossed progeny at the Coconut Research Institute. However, when traced back all surviving selfed and outcrossed progeny at Bandirippuwa Estate narrows down to a single mother palm (Fernando 1987). This paper reviews the performance of selfed and open pollinated San Ramon derived from this palm and the subsequent plantations established by propagating the above and the steps taken to widen its genetic base.

San Ramon has three main colour forms green, brownish red (russet) and an intermediate shade of orange green (bronze) (CRI 1987). The trunk of San Ramon palms is erect and large in size, both in height and girth compared to 
ordinary tall coconut and consists of a massive bole at the foot of the palm. A mean trunk height of $19 \mathrm{~m}$ was recorded for a sample of 100 San Ramon palms from the Uhumiya collection as against a mean of $15 \mathrm{~m}$ was recorded for a standard tall population of similar age from Palugaswewa estate, Rajakadaluwa, Chilaw (CRI 1987; 1988). A study conducted by Palomar (1994) on the wood quality of San Ramon timber has shown that the brown type trees recorded significantly higher values in all the mechanical properties relevant to timber quality than the green type trees. The nuts of San Ramon have a characteristic round shape with a flat bottom. The ratio of polar to equatorial circumference is 1.07 for San Ramon nuts compared to the ratio of standard tall palm nuts being 1.19 (CRI 1987). The form San Ramon is believed to be originated from Mindanao islands the Philippines where frequent fluctuations in.climatic conditions are experienced and as a result the cultivar may have accumulated favourable genes over a long period of adaptation (Santos 1984). In a study carried out on 7 tall populations in the Philippines, Balingasa and Carpio (1983) reported that San Ramon had the lowest coefficient of variability for bunch characteristics.

\section{MATERIAL AND METHODS}

Seven open pollinated and sixteen selfed progenies obtained from the San Ramon mother palm No.1870 (arising from the Uhumiya collection and planted at Bandirippuwa Estate) were established in field No's 9 and 16 of the Bandirippuwa Estate in 1960 and 1975 respectively. The time taken for flowering of individual palms were recorded whilst the nut yield recording and fruit component analysis were undertaken during 1984 and 1985. For the fruit component analyses, weight of fruit, husked nut, nut water and kernel were recorded for 5 nuts from each palm and at each pick and the mean was. calculated. The copra content per nut was estimated as $32 \%$ of the husked nut weight.

The open pollinated San Ramon palm numbers 64, 65, 68 and 69 of field No.9 Bandirippuwa Estate were selfed and crossed during 1984/85 and the resulting progeny was established at the $\mathbf{5 0}$ acre block at Bandirippuwa Estate in July 1986 (CRI 1986) and serves as the field gene bank for San Ramon. The time taken for germination of above seed nuts arising from palm numbers $64,65,68$ and 69 , vegetative growth parameters and flowering time of the resulting progeny were recorded.

Pollen of selfed San Ramon palms (No.s 4, 14, 15, 16, 17 and 18) from field No.16 Bandirippuwa Estate were used in a crossing programme on selected Ambakelle tall palms (CRI 1985) and the resulting progeny was planted along with Tall $x$ Tall and Tall $x$ Dwarf green progeny in a series of 
multi-locational trials during 1986/87 in order to assess the performance of these crosses in different agro-climatic regions (CRI 1986). The mean time taken for flowering was recorded for the 3 crosses at the sites Bandirippuwa, Ratmalagara, Mangala-eliya, Andigama and Daisy Valley whilst the nut yield and weights of fruit components were recorded at the first two sites during 1996-1997.

\section{RESULTS AND DISCUSSION}

\section{Fruit component analyses}

Data on fruit components of nuts from open pollinated and selfed San Ramon palms from Bandirippuwa Estate during 1984/85 are given in Table 1 along with data obtained for fruit components of standard cultivars from Isolated Seed Garden at Ambakelle (CRIC 60) and CRIC 65) and Marandawila Estate, Bingiriya (Plus palm) during the same period. A difference is observed in fruit components for nuts obtained from open pollinated and selfed palms. However, San Ramon records the highest fruit weight and also husked nut weight irrespective of the method of pollination. Data indicates that the percentage of husk and shell are both less in nuts obtained from selfed and open pollinated San Ramon palms compared to other standard cultivars. Even though, the large size of the nut, provides a higher weight for both components, the thickness of the shell and husk is lesser than the nuts of other tall cultivars leading to breakage of the shell when picked from tall palms. The increased kernel weight of San Ramon nuts provides an advantage to the copra industry as the cost of production is lesser with a smaller amount of nuts required for a candy of copra.

\section{Time to flower and yield}

The mean time taken for flowering of the open pollinated and selfed palms of field No's 9 and 16 of Bandirippuwa Estate is 58 and 62 months from planting respectively. The yield figures recorded on these two sets of palms for the two years 1984 and 1985 in which contrasting effects of climatic variations were experienced are summarized in Table 2. The annual rainfall at Bandirippuwa was $1472 \mathrm{~mm}$ and $1973 \mathrm{~mm}$ for 1983 and 1984 respectively. The mean number of nuts/palm at Bandirippuwa was 28 and 45 in 1984 and 1985 respectively as the effect of climatic conditions of the previous year had a significant effect on the yield of the current year. Comparing the mean nut yield at Bandirippuwa Estate with the individual yield records of San Ramon palms it is evident that all open pollinated San Ramon palms have performed well above the average nut yield of the estate. But the selfed San Ramon palms have shown 
large fluctuation in their annual yield elucidating the highly heterogenous nature of individual palms. However superior palms producing $56 \mathrm{~kg} / \mathrm{copra} / \mathrm{palm} / \mathrm{yr}$ were found both in selfed and open pollinated categories of San Ramon when the mean copra yield for the estate was $6 \mathrm{~kg} / \mathrm{palm} / \mathrm{yr}$. (CRI, 1984; 1985).

Table 1. Weights and percentages of fruit components of San Ramon compared with the standard coconut cultivars

\begin{tabular}{|c|c|c|c|c|c|c|c|c|}
\hline Cultivar & $\begin{array}{l}\text { Mean } \\
\text { fruit } \\
\text { weight } \\
\text { (g) }\end{array}$ & $\begin{array}{l}\text { Mean } \\
\text { husk } \\
\text { weight } \\
\text { (g) }\end{array}$ & $\begin{array}{l}\% \\
\text { husk } \\
\text { per } \\
\text { fruit }\end{array}$ & $\begin{array}{l}\text { Mean } \\
\text { nut } \\
\text { weight } \\
\text { (g) }\end{array}$ & $\begin{array}{l}\text { Mean } \\
\text { shell } \\
\text { weight } \\
\text { (g) }\end{array}$ & $\begin{array}{l}\% \\
\text { shell } \\
\text { per } \\
\text { nut }\end{array}$ & $\begin{array}{l}\text { Mean } \\
\text { kernel } \\
\text { weight } \\
\text { (g) }\end{array}$ & $\begin{array}{l}\% \\
\text { kernel } \\
\text { per nut }\end{array}$ \\
\hline $\begin{array}{l}\text { San } \\
\text { Ramon } \\
\text { (selfed) }\end{array}$ & 2150 & 990 & 46.04 & 1160 & 280 & 13.02 & 530 & 24.65 \\
\hline $\begin{array}{l}\text { San } \\
\text { Ramon } \\
\text { (OP) }\end{array}$ & 2360 & 1070 & 45.33 & 1290 & 290 & 12.22 & 650 & 27.54 \\
\hline $\begin{array}{l}\text { Tall } \\
\text { (Plus } \\
\text { palm) }\end{array}$ & 1380 & 628 & 55.11 & 710 & 230 & 16.66 & 374 & 27.10 \\
\hline $\begin{array}{l}\text { CRIC } 60 \\
\text { (Tall } x \\
\text { Tall) }\end{array}$ & 1517 & 748 & 49.53 & 769 & 204 & 13.44 & 378 & 24.97 \\
\hline $\begin{array}{l}\text { CRIC } 65 \\
\text { (Dwarf x } \\
\text { Tall) }\end{array}$ & 1327 & 640 & 48.19 & 687 & 173 & 13.03 & 348 & 26.22 \\
\hline
\end{tabular}

Comparison of third generation self and cross progenies of San Ramon

The time taken for germination of self and crossed seed nuts arising from palm numbers 64,65 , and 68, vegetative growth parameters and flowering time of the resulting progeny established in the field gene bank for San Ramon at Bandirippuwa Estate are given in Table 3. The data indicates that out of the 3 progeny families arising from 68 self, $65 \times 68$ cross and 64 self, the progeny family arising from 68 self, flowered early with a mean of 56 months indicating that selfing could also lead to an improvement depending on the genotype (Fernando and Perera 1996). Even though the progeny family of $65 \times 68$ flowered later than 68 self, it germinated early and recorded the highest mean leaf production at the rate of 4.68 new leaves per 6 months during the period 6-54 months from planting. Thirty San Ramon palms 
arising from the above families with desirable genetic and agronomic characters were selected as female parents for a further population improvement in 1996 and these palms were pollinated with San Ramon pollen obtained from the Uhumiya collection and also from parental palms 64 and 65 of field No. 9 Bandirippuwa Estate (CRI 1996). The resulting seed would be used to raise seedlings for the establishment of the Pallama seed garden due to be established to mass propagate the cross Tall $x$ San Ramon (CRISL 98).

Table 2. Yield and flowering time of selfed and open pollinated San Ramon progenies during 1984/85 planted at Bandirippuwa Estate and arising from parent palm 1870/BE

\subsection{San Ramon (open pollinated)}

\begin{tabular}{|c|c|c|c|c|c|c|c|c|c|}
\hline \multirow[t]{2}{*}{$\begin{array}{l}\text { Palm } \\
\text { No. }\end{array}$} & \multirow{2}{*}{$\begin{array}{c}\text { Flowering } \\
\text { period } \\
\text { (mths) }\end{array}$} & \multicolumn{2}{|c|}{ Nuts/yr } & \multicolumn{2}{|c|}{$\begin{array}{l}\text { Wt. of husked } \\
\text { nut ( g) }\end{array}$} & \multicolumn{2}{|c|}{$\begin{array}{l}\text { Copra/nut } \\
\text { (g) }\end{array}$} & \multicolumn{2}{|c|}{$\begin{array}{c}\text { Copra/palm/yr } \\
\text { (kg) }\end{array}$} \\
\hline & & 1984 & 1985 & 1984 & 1985 & 1984 & 1985 & 1984 & 1985 \\
\hline 64 & 84 & 100 & 47 & 1230 & 1500 & 393 & 480 & 39.3 & 22.6 \\
\hline 65 & 68 & 90 & 75 & 1280 & 1440 & 410 & 460 & 36.9 & 34.5 \\
\hline 66 & 66 & 141 & 147 & 1240 & 1170 & 397 & 373 & 55.9 & 54.8 \\
\hline 67 & 44 & 137 & 157 & 1270 & 1410 & 408 & 451 & 55.8 & 70.8 \\
\hline 68 & 54 & 84 & 69 & 1220 & 1320 & 390 & 421 & 32.7 & 29.0 \\
\hline 69 & 46 & 71 & 21 & 1390 & 1790 & 442 & 575 & 31.4 & 12.1 \\
\hline 70 & 47 & 87 & 86 & 1440 & 1390 & 461 & 447 & 40.1 & 38.5 \\
\hline Mean & 58 & 101 & 85 & 1290 & 1430 & 414 & 458 & 41.8 & 38.9 \\
\hline
\end{tabular}

\section{Progeny Testing of Tall $x$ San Ramon}

Data obtained from the evaluation of the crosses Tall $x$ San Ramon ( $T x$ SR), Tall $\times$ Tall $(T \times T)$ and Tall $\times$ Dwarf green (TxDG) at multi-location sites for flowering time are shown in Table 4 and the initial yield of the 3 crosses at the sites Ratmalagara and Bandirippuwa Estates are given in Table 5. Results indicate that between the two tall crosses Tall $x$ Tall and Tall $x$ San Ramon, the latter flowered early with a mean of 78 months from planting. However the performance at sites with sandy loam/loamy sand was significantly better than lateritic gravel (Andigama). Further the difference among sites in the performance of Tall $x$ San Ramon was least when compared with Tall $x$ Tall indicating the stability of the cross in different environments (Fernando, 1994). 


\subsection{San Ramon (selfed)}

\begin{tabular}{|c|c|c|c|c|c|c|c|c|c|}
\hline \multirow{2}{*}{$\begin{array}{l}\text { Palm } \\
\text { No. }\end{array}$} & \multirow{2}{*}{$\begin{array}{c}\text { Flowering } \\
\text { period } \\
\text { (mths) }\end{array}$} & \multicolumn{2}{|c|}{ Nuts/yr } & \multicolumn{2}{|c|}{$\begin{array}{l}\text { Wt. of husked } \\
\text { nut (g) }\end{array}$} & \multicolumn{2}{|c|}{ Copra/nut (g) } & \multicolumn{2}{|c|}{$\begin{array}{c}\text { Copra/palm/yr } \\
(\mathrm{kg})\end{array}$} \\
\hline & & 1984 & 1985 & 1984 & 1985 & 1984 & 1985 & 1984 & 1985 \\
\hline 2 & 57 & 45 & 58 & 756 & 912 & 242 & 292 & 10.8 & 16.9 \\
\hline 4 & 60 & 46 & 75 & 1630 & 1430 & 522 & 458 & 24.0 & 34.3 \\
\hline 6 & 75 & 35 & 58 & 702 & 1341 & 225 & 429 & 7.9 & 24.9 \\
\hline 11 & 83 & 13 & 49 & 1230 & 1690 & 394 & 541 & 5.1 & 26.5 \\
\hline 13 & 69 & 19 & 39 & 1100 & 1250 & 352 & 400 & 6.7 & 15.6 \\
\hline 16 & 54 & 121 & 116 & 1460 & 1709 & 467 & 546 & 56.5 & 63.3 \\
\hline 17 & 52 & 39 & 44 & 1346 & 1527 & 431 & 418 & 16.8 & 18.3 \\
\hline 18 & 53 & 108 & 118 & 1099 & 1144 & 352 & 366 & 38.0 & 43.2 \\
\hline 20 & 60 & 67 & 95 & 1311 & 1186 & 419 & 379 & 28.1 & 36.0 \\
\hline Mean & 62 & 55 & 72 & 1181 & 1354 & 378 & 425 & 21.6 & 38.1 \\
\hline
\end{tabular}

Table 3. Time to germinate, flowering time and rate or leaf production of the progeny families arising from palm Nos. 64,65 and 68

\begin{tabular}{|c|c|c|c|c|c|c|}
\hline \multirow[t]{2}{*}{ Cross } & \multirow[t]{2}{*}{$\begin{array}{c}\text { No. of } \\
\text { offspring }\end{array}$} & \multicolumn{2}{|c|}{$\begin{array}{l}\text { Germination } \\
\text { time (days) }\end{array}$} & \multirow{2}{*}{$\begin{array}{l}\text { Rate of leaf } \\
\text { production } \\
\text { (mean no. leaves } \\
\text { produced/6 } \\
\text { months) }\end{array}$} & \multicolumn{2}{|c|}{$\begin{array}{l}\text { Flowering time } \\
\text { (months) }\end{array}$} \\
\hline & & Mean & Range & & Mean & Range \\
\hline $\begin{array}{l}68 \times 68 \\
65 \times 68 \\
64 \times 64\end{array}$ & $\begin{array}{l}29 \\
23 \\
34\end{array}$ & $\begin{array}{l}116 \\
105 \\
121\end{array}$ & $\begin{array}{l}93-139 \\
73-132 \\
90-159\end{array}$ & $\begin{array}{l}4.44 \\
4.68 \\
4.21\end{array}$ & $\begin{array}{l}56 \\
69 \\
76\end{array}$ & $\begin{array}{l}40-91 \\
51-93 \\
77-109\end{array}$ \\
\hline
\end{tabular}

The extent of stress tolerance in San Ramon was investigated by Ranasinghe (1989) and reported that the levels of total soluble sugars, starch content and proline content were significantly higher both in San Ramon and its cross with tall (Tall $x$ San Ramon) when compared with the standard tall (Table 7). Accumulation of proline under water deficit has been shown to be a sensitive indicator of drought tolerance in annual crops (Singh et al., 1973) and Jayasekara et al. (1992) confirmed this phenomenon for coconut since higher concentrations of proline accumulation was observed during dry conditions for genotypes identified as stable when assessed for drought sensitive physiological parameters. 
Table 4. The mean flowering time (months) of the 3 crosses, $T \times S R, T \times T$ and $T \times D G$ assessed in the 5 multi-locational sites. $\quad(B E=$ Bandirippuwa; $\mathrm{RE}=$ Ratmalagara; $\mathrm{ME}=$ Mangala Eliya; the year of establishment is given within brackets)

\begin{tabular}{lccccccc}
\hline & $\begin{array}{c}\text { BE } \\
(1986)\end{array}$ & $\begin{array}{c}\text { RE } \\
(1986)\end{array}$ & $\begin{array}{c}\text { ME } \\
(1987)\end{array}$ & $\begin{array}{c}\text { Andigama } \\
(1986)\end{array}$ & $\begin{array}{c}\text { Daisy } \\
\text { Valley } \\
(1986)\end{array}$ & Mean & Range \\
\hline & & & & & & & \\
T x T & 70 & 84 & 82 & 110 & 81 & 85.4 & $70-110$ \\
T x DG & 44 & 54 & 61 & 66 & 53 & 55.6 & $44-66$ \\
Tx SR & 71 & 70 & 78 & 100 & 72 & 78.2 & $70-100$ \\
\hline
\end{tabular}

Considering the yield potential of tall cultivars, Tall $x$ San Ramon performed equally well as Tall $x$ Tall (CRIC 60) (Table 5) for nut number but the fruit component analysis shows that Tall $x$ San Ramon produced larger nuts with higher kernel weight (Table 6) leading to an increased copra outturn per palm. Recent studies on oil extraction efficiency of copra have shown that the amount of oil extracted/kg of copra was $776 \mathrm{ml}$ for Tall $x$ San Ramon whilst for both Tall $x$ Tall (CRIC 60) and ordinary tall varieties this amount is $740 \mathrm{ml}$ (CRI 1997). Considering the minute genetic variation present for oil concentration among the coconut varieties in Sri Lanka, San Ramon would be a promising source to be used in the future oil industry.

Table 5. Nut yield (nuts/palm/yr) of the 3 crosses at Bandirippuwa and Ratmalagara Estates during the years 1995-1997 (within year values with the same letter are not significantly different; $P>0.05$ )

\begin{tabular}{lcccccc}
\hline Treatment & \multicolumn{3}{c}{ Bandirippuwa } & \multicolumn{3}{c}{ Ratmalagara } \\
\cline { 2 - 7 } Variety & 1995 & 1996 & 1997 & 1995 & 1996 & 1997 \\
\hline & & & & & & \\
T x DG & $54 \mathrm{a}$ & $53 \mathrm{a}$ & $50 \mathrm{a}$ & $28 \mathrm{a}$ & $37 \mathrm{a}$ & $42 \mathrm{a}$ \\
T x T & $39 \mathrm{~b}$ & $34 \mathrm{~b}$ & $33 \mathrm{~b}$ & $17 \mathrm{~b}$ & $25 \mathrm{~b}$ & $30 \mathrm{~b}$ \\
T x SR & $28 \mathrm{c}$ & $28 \mathrm{c}$ & $28 \mathrm{c}$ & $17 \mathrm{~b}$ & $28 \mathrm{~b}$ & $35 \mathrm{~b}$ \\
\hline
\end{tabular}




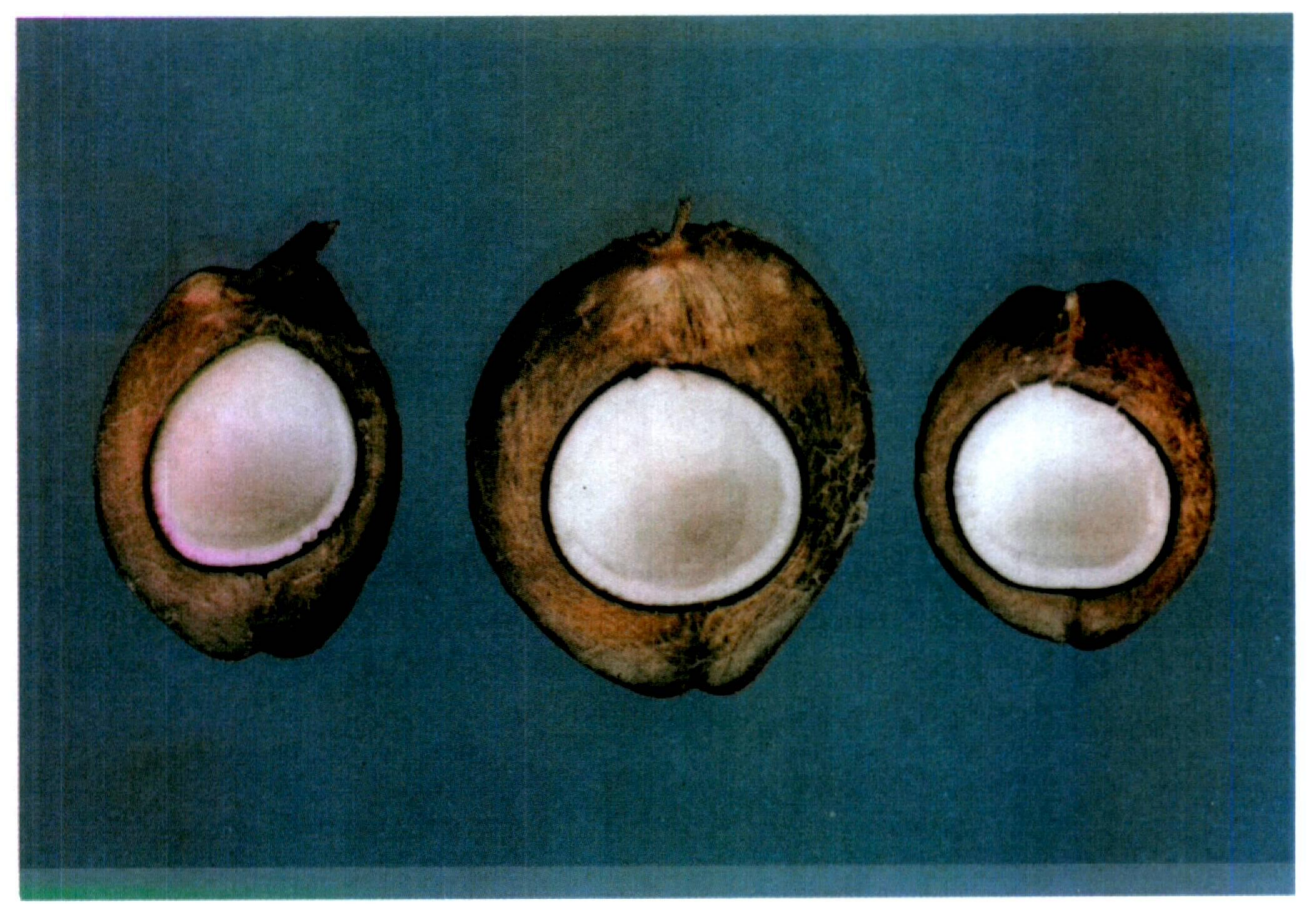

Figure 1. Cross sections of the fruits of Sri Lanka Tall (left), San Ramon (middle) and Tall x San Ramon (right).

Table 6. Fruit components of the 3 crosses during 1996, 1997 and the two year mean

\begin{tabular}{lccccccccc}
\hline Character & \multicolumn{3}{c}{1996} & \multicolumn{3}{c}{1997} & \multicolumn{3}{c}{ Mean } \\
\cline { 2 - 8 } & T x T & T x DG & T x SR & T x T & T x DG & T x SR & T x T & T x DG & T x SR \\
\hline $\begin{array}{l}\text { Fruit weight } \\
\text { (g) }\end{array}$ & 1289 & 143 & 1534 & 1379 & 1181 & 1712 & 1334 & 1162 & 1624 \\
$\begin{array}{l}\text { Kernel } \\
\text { weight (g) }\end{array}$ & 337 & 325 & 405 & 382 & 336 & 457 & 360 & 330 & 4.31 \\
$\begin{array}{l}\text { Copra/ } \\
\text { nut (g) }\end{array}$ & 217 & 192 & 265 & 251 & 220 & 307 & 237 & 206 & 286 \\
$\begin{array}{l}\text { Copra/ } \\
\text { palm (kg) }\end{array}$ & 7.4 & 10.2 & 7.4 & 7.5 & 9.2 & 9.2 & 7.5 & 9.7 & 8.3 \\
\hline
\end{tabular}


Table 7. Biochemical constituents in the leaf during wet and dry periods of Tall x San Ramon and its parental varieties

\begin{tabular}{lcccccc}
\hline \multirow{2}{*}{ Cultivar } & \multicolumn{2}{c}{$\begin{array}{c}\text { Total soluble sugars } \\
\text { (mg/g dry wt.) }\end{array}$} & \multicolumn{2}{c}{$\begin{array}{c}\text { Stärch content } \\
\text { (mg/g dry wt.) }\end{array}$} & \multicolumn{2}{c}{$\begin{array}{c}\text { Proline content } \\
\text { (mg/g dry wt.) }\end{array}$} \\
\cline { 2 - 7 } & Wet & Dry & Wet & Dry & Wet & Dry \\
\hline Tall & 14.2 & 8.6 & 7.2 & 7.4 & 73 & 253 \\
San Ramon & 70.2 & 19.8 & 11.0 & 10.5 & 127 & 351 \\
$\begin{array}{l}\text { Tall } x \text { San } \\
\text { Ramon }\end{array}$ & 54.1 & 11.7 & 14.2 & 11.3 & 143 & 434 \\
\hline
\end{tabular}

\section{ACKNOWLEDGEMENTS}

The author wishes to acknowledge Drs. D $\dot{V}$ Liyanage and M R T Wikramaratne former Botanists of CRI for their efforts to initiate the above trials and to maintain long term records of data. The skilled assistance provided by Mr. J H Somaratne, Field Attendant Genetics \& Plant Breeding Division in carrying out tedious hand pollinations are acknowledged.

\section{REFERENCES}

Balingasa, E. B. and Carpio, C. B. (1983). Genetic potential of some coconut populations of Philippines. In: Coconut Research and development (Ed) N M Nayar:71-81.

CRI (1984). Report of the Genetics \& Plant Breeding Division pp 42-74. In: Annual Report of the Coconut Research Institute for 1984 CRI Lunuwila, Sri Lanka.

CRI (1985). Report of the Genetics \& Plant Breeding Division 41-87 In: AnnualReport of the Coconut Research Institute for 1985 CRI Lunuwila, Sri Lanka.

CRI (1986). Report of the Genetics \& Plant Breeding Division In: Annual Report of the Coconut Research Institute for 1986 CRI Lunuwila, Sri Lanka.

CRI (1987). Report of Genetics \& Plant Breeding Division p 51-107 In:

Annual Report of the Coconut Research Institute for 1987 CRI Lunuwila, Sri Lanka. 
CRI (1996). Report of the Genetics \& Plant Breeding Division In: Annual Report of the Coconut Research Institute for 1996 CRI Lunuwila, Sri Lanka.

CRI (1997). Annual Report of the Coconut Research Institute for 1997 CRI Lunuwila, Sri Lanka.

Fernando, W. M. U. (1987). San Ramon big with promise - Coconut Bulletin 4(1): 15 .

Fernando, W. M. U. (1994). Genetic assessment of three improved crosses of coconut. Proc. Sri Lanka Assoc. Advmt. Sci. 50(2):70.

Fernando, W. M. U. and Perera, L. (1996). Patterns of segregation in the $F_{2}$ generation of dwarf $\mathrm{x}$ tall crosses of Cocos nucifera with special reference to reproductive characters. Journal of Plantation Crops (Supp.). 24:447452 .

Jayasekara, C., Ranasinghe; C. S. and Mathes, D. T. (1992). Screening for high yield and drought tolerance in coconut In: Coconut Research and Development (Ed) M K Nayar:209-217.

Palomar, R. N., Fernandz, V. A. (1994). Variability of some mechanical properties of coconut wood. PJCS 19(2):5-14.

Ranasinghe, C. S. (1989). Physiological and biochemical characters of different varieties of coconut. Proc. of Sri Lanka Association for Advmt. Sci. 45(2):55.

Santos, G. A., Cano, S. B., dela. Cruz, B V, Ilagan, M. C. and Bahala, R. T. (1984). Coconut germplasm collection in the Philippines PJCS $\mathrm{IX}(1 / 2): 1$ 9.

Singh, T. N., Paleg, L. G. and Aspinall, D. (1973). Stress metabolism. I. Nitrogen metabolism and growth in the barley plant during water stress. Aust. J. Biol. Sci. 26:65-76. 